
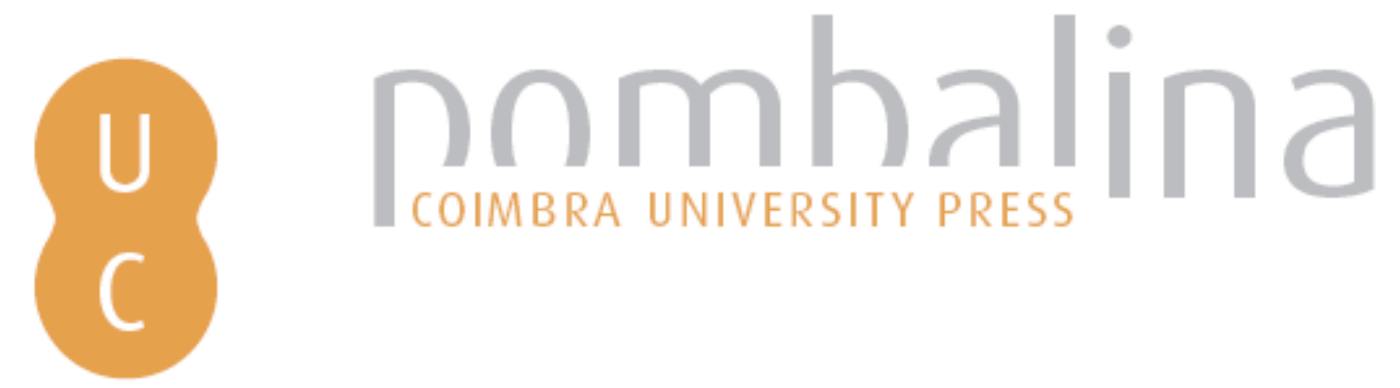

\title{
Monitoring of forest fire risk conditions in Portugal with NOAA/NESDIS satellite- based Vegetation Health Index
}
Autor(es):
Bugalho, Lourdes; Camara, Natália; Kogan, F.N
Publicado por: Imprensa da Universidade de Coimbra
URL
persistente:
URI:http://hdl.handle.net/10316.2/44527
DOI:
DOI:https://doi.org/10.14195/978-989-26-16-506_10
Accessed : $\quad$ 26-Apr-2023 13:03:49

A navegação consulta e descarregamento dos títulos inseridos nas Bibliotecas Digitais UC Digitalis, UC Pombalina e UC Impactum, pressupõem a aceitação plena e sem reservas dos Termos e Condições de Uso destas Bibliotecas Digitais, disponíveis em https://digitalis.uc.pt/pt-pt/termos.

Conforme exposto nos referidos Termos e Condições de Uso, o descarregamento de títulos de acesso restrito requer uma licença válida de autorização devendo o utilizador aceder ao(s) documento(s) a partir de um endereço de IP da instituição detentora da supramencionada licença.

Ao utilizador é apenas permitido o descarregamento para uso pessoal, pelo que o emprego do(s) título(s) descarregado(s) para outro fim, designadamente comercial, carece de autorização do respetivo autor ou editor da obra.

Na medida em que todas as obras da UC Digitalis se encontram protegidas pelo Código do Direito de Autor e Direitos Conexos e demais legislação aplicável, toda a cópia, parcial ou total, deste documento, nos casos em que é legalmente admitida, deverá conter ou fazer-se acompanhar por este aviso.

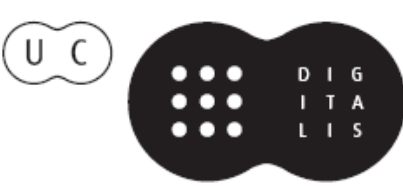




\section{ADVANCES IN}

\section{FOREST FIRE RESEARCH}

\section{8}

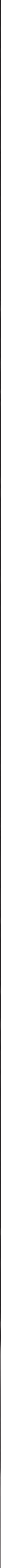




\title{
Monitoring of forest fire risk conditions in Portugal with NOAA/NESDIS satellite-based Vegetation Health Index
}

\author{
Lourdes Bugalho*1; Natália Camara ${ }^{1}$; F.N. Kogan ${ }^{2}$ \\ ${ }^{1}$ Instituto Português do Mar e da Atmosfera, Rua C do Aeroporto, Lisboa, 1749-077, Portugal. \\ \{lourdes.bugalho@ipma.pt*; natalia.camara@ipma.pt\} \\ ${ }^{2}$ NOAA/NESDIS Center for Satellite Applications and Research, Washington DC, USA
}

\begin{abstract}
NOAA/NESDIS satellite-based Vegetation Health Index (VHI) was applied to study wildfire favourable environmental conditions for period 2001-2017.VHI consists of two terms: Vegetation Condition Index (VCI), and Temperature Condition Index (TCI), which reflect vegetation moisture conditions and vegetation thermal conditions. Joint analysis of drought conditions $(\mathrm{VHI}<40)$ and vegetation stress $(\mathrm{VCI}, \mathrm{TCI}<40)$ on the one hand and burned area and number of fires on the other hand showed, that $88 \%$ of big fires in Portugal have relation with droughts or vegetation stress.
\end{abstract}

Keywords: Forest Fire Risk monitorization, Vegetation Health Index, vegetation stress, droughts

\section{Intoduction}

In the Mediterranean region forest fires are usual phenomenon in conditions summer or hot and dry spring / autumn, being one of the severe natural disasters during the summer months. Portugal is one of the European countries most affected by wildfire. So it is very important to effectuate weather and environmental monitoring of wildfire risks conditions. Unfortunately, there are no regular observations of soil water content and density of meteorological stations is not enough for this purpose. At present time, remote sensing of earth surface from operational satellites have become powerful tools to realize fire risk monitoring. Thus, some satellite-based vegetation indices, like Normalized Difference Vegetation Index (NDVI) and Enhanced Vegetation Index (EVI), have been generally used to model forest fire danger (Illera, P. et al, 2007, Bisquert, Mar et al, 2014).

Fire favourable conditions and fire regime characteristics (burned area, frequency, and severity) are controlled by weather and climate. Numerous studies indicate the relationship between droughts and wild fires. Drought determines forest productivity and fuel state and thus affects fire intensity and severity.

In this work we intend to show the application of the NOAA/NESDIS satellite-based Vegetation Health Index (VHI) for monitoring of wildfire risk conditions in Portugal. During the last 20 years Vegetation Health ( $\mathrm{VH}$ ) indices method was developed, tested, validated and applied globally and regionally (https://www.star.nesdis.noaa.gov/smcd/emb/vci/VH/vh_ftp.php). The VHI represents the moisture-thermal vegetation health and combines two indices: Temperature Condition Index (TCI) and Vegetation Condition Index (VCI). The VCI reflects the vegetation moisture conditions and TCI reflects the vegetation thermal conditions. (Kogan 1997). VCI and TCI reflect vegetation response to weather changes, because climatic signals are removed, using climatic extremes. These indices were successfully used for monitoring droughts, environmentally-based vegetation stress, fire risk, soil saturation and other natural hazards around the world.This study is focused on the relationship of the VHI and its terms (VCI and TCI) to the most severe forest fires ( $\geq 1000 \mathrm{ha})$ in Portugal in period 20012017. 
Droughts events have important impact on the forest fires conditions, since precipitation deficit reduces soil and fuel moisture, that lead to ease ignition and spread of forest fire (Shoennagel et al.,2004, Jurdao et al.,2012).

The relationship between drought and forest fires conditions seems simple, but it is difficult analyse because the fire favourable conditions depend on human impact as well as environmental. Many of the causes of forest fires are results of human activities or negligence. On the other hand, the forest fires have an impact on the human habitat, altering type of the soil cover and vegetation, leading to degradation of the soils.

\section{Vegetation Healthy Index (VHI) and Droughts}

The NOAA/NESDIS Vegetation Health (VH) method is based on the properties of green vegetation to reflect sunlight and emit absorbed solar radiation.

Pigmentation of the plants leaves, chlorophyll, strongly absorbs light in a visible part (VIS) of the spectrum $(0.4$ to $0.7 \mu \mathrm{m})$ for use in the photosynthesis process. On the other hand, the cell structure of the leaves strongly reflects the light in part of the near infrared spectrum (NIR). Healthy and without water stress vegetation has a reduced VIS and enlarged NIR, resulting in higher NDVI. Healthy vegetation absorbs and emits less thermal IR radiation, resulting in lower BT and cooler canopy. Drought depresses vegetation greenness, decreases vigor and makes the canopy hot due to an increase in VIS (following chlorophyll depletion), decrease in NIR (following a drop in water content), a reduction of NDVI and an increase in thermal IR and BT values (Cracknell 1997; Kogan 2001).

NDVI and BT indices contain three environmental signals: ecosystem, climate and real-time weather (precipitation, temperature etc.). Unfortunately, the ecosystem/climate signal has much stronger contribution in the NDVI and BT values, compared to the weather. Therefore, in order to estimate weather impacts on land surface, the values of climate/ecosystem were removed from these indices, normalizing them to their climatology. This procedure was performed by calculating a NDVI and BT climatology following three biophysical laws: the Leibig's Low-of-Minimum, the Shelford's Low-of-Tolerance and the Principal of Carrying Capacity (Kogan 1995, 2001, Kogan et al., 2003).

Thus, NDVI and BT values were expressed as deviations from climatologic extremes and became:

-Vegetation Conditions Index (VCI) - a proxy of vegetation moisture conditions

$$
\text { VCI }=100 *(\text { NDVI-NDVImin) } /(\text { NDVImax-NDVImin) }
$$

-Temperature Conditions Index (TCI) - a proxy of the thermal conditions of vegetation

$$
\text { TCI }=100 *(\text { BTmax }-B T) /(\text { BTmax-BTmin })
$$

-Vegetation Health Index (VHI), which presents a combination of the first two

$$
\mathrm{VHI}=\alpha * \mathrm{VCI}+(1-\alpha) * \mathrm{TCI}, \alpha=0.5
$$

BTmax, NDVImax, BTmin, NDVImin are the maximum and minimum values of NDVI and BT for each week during the observation period of 36 years. They represent the extreme climatologic thresholds of the weekly values of the NDVI and BT variations due to the change in time. Differences (NDVImax-NDVImin) and (BTmax-BTmin) reflect the level of climate variability.

Thus, expressions for VCI and TCI show the percentage of deviation of the NDVI and BT values of extreme climatologic thresholds and reflects vegetation stress due to lack of soil water and excessive heating.

Each index (VCI, TCI and VHI) varies from zero, characterizing the extreme stress of vegetation, up to 100 , characterizing optimal conditions for vegetation. For many agricultural crops, a reduction of $\mathrm{VH}$ indices below 40 correlates with a reduction of crop yield below long-term mean or trend 
(Kogan et al., 1998, Kogan and Guo 2014, 2015). Therefore, the value of indices below 40 was accepted as the beginning of a drought (Kogan 2001). Drought intensifies when the indices decrease from 40 (mild drought) to 0 (exceptional drought). The criterion for drought intensity was established based on crop yield correlation with VH indices (Hayas and Decker 1996. Kogan et al., 1998, Kogan and Guo 2014). The VH indices have been validated in 29 countries and used globally since the 2000s, approximating vegetation condition. VH-based drought assessments include drought area, intensity, duration and origination (either from moisture or thermal or both), crop and pasture losses, wildfire risk, and drastic changes in conditions over time.

\section{Data e methodology.}

NOAA/NESDIS Advanced Very High Resolution Radiometer's (AVHRR) data were used in this study. The Advanced Very High Resolution Radiometer (AVHRR) was installed in NOAA polar orbiting satellites during 1981-2017. The AVHRR sensor measured in the visible (VIS 0.58-0.68 $\mu \mathrm{m}$, band1), near infrared (NIR,0.72-1.00 $\mu \mathrm{m}$, band2) and infrared (IR, 10.3-11.3 $\mu \mathrm{m}$ band4 and 11.3-12.3 $\mu \mathrm{m}$, band5). These data are global, with the resolution of $4 \mathrm{~km}$ and are composed of 7 days.

TCI, VCI and VHI-indices were collected for Portugal Continental for period 2000-2017. (ftp://ftp.star.nesdis.noaa.gov/pub/corp/scsb/wguo/data/VHP 4km/VH ). From collected data and using VHI method for each of 18 districts of Portugal were calculated: 1) average values of VHIindices, averaging the values of the VHI indices within the district area and 2) percentage of area of districts with the droughts, detected with VHI indices.

The fires information (burned areas and number of occurrences of forest fires) is the responsibility of the Institute of Nature Conservation and Forests, (http://www.icnf.pt ), which provide daily fire occurrence for each of the 18 districts of Portugal. Data were obtained from January 1, 2001 to December 31, 2017 and for each year were accumulated for periods of 7 days between January 1 to December 31

The processed VHI data were matched with data of wild forest fires (number of fires and burned areas). The goal was to investigate how vegetation conditions and local droughts, detected with VHImethod, coincide with occurred fires.

In fires researches there is no direct and simple relation among natural causes and their consequences due to human and socioeconomic impact. By these reasons it is difficult to obtain good results in statistical analyses of impact of droughts, vegetation stress or other natural conditions which favor forest fires.

Two methods were used to relate drought and vegetation stress with burned areas (or number of events):

1. Graphical use to visualize the dynamic of average values of VHI, VCI, TCI and percentage of drought and the burned area or number of occurrences. The visual analysis was done weekly by district for the period 2001 to 2017 .

2. For this study, the relationships between the burned area with values equal to or higher 1000 ha and the percentage of dry area of the district with values equal to or higher 20 were analyzed, that means more than $20 \%$ of the district in a dry condition. For this purpose, the analysis by contingency table was used and the probabilities of detection (POD), the false alarm rate (FAR), and the miss ratio, were calculated. 


\section{Contingency Table}

\begin{tabular}{|l|c|c|c|}
\hline \multirow{4}{*}{$\begin{array}{l}\text { \%drought } \geq 20 \\
\text { \%drought }<20\end{array}$} & burntarea $\geq 1000$ ha & burntarea $<1000$ ha \\
\cline { 2 - 3 } & $\mathrm{a}$ & $\mathrm{b}$ & $\mathrm{a}+\mathrm{b}$ \\
& $\mathrm{c}$ & $\mathrm{d}$ & $\mathrm{c}+\mathrm{d}$ \\
\cline { 2 - 4 } & $\mathrm{a}+\mathrm{c}$ & $\mathrm{b}+\mathrm{d}$ \\
\hline
\end{tabular}

The probability of detection (POD) is: $P O D=\frac{a}{a+c}$

The false alarm rate (FAR) is: $F A R=\frac{b}{a+b}$

The miss ratio: $M R=\frac{c}{c+d}$

To complete the study it was also analyzed the relationship between the number of weeks with burned area equal or exceeding 1000 ha and the percentile of dryness for each district.

\section{Results and Discussion}

Droughts are part of climate of Portugal. The deep, severe and extreme droughts always start with local droughts, which can transform later in a severe. In Portugal local droughts occur every year and can be detected using VHI-method (Figure1).

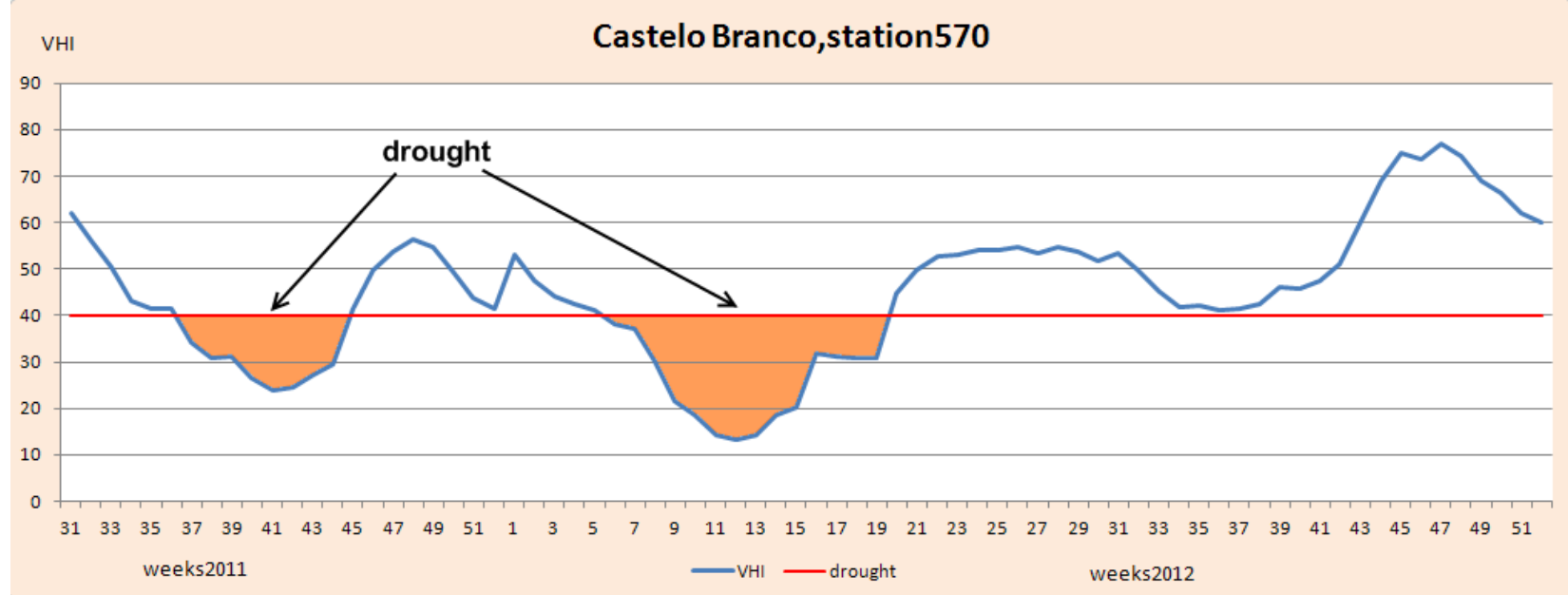

Figure 1 - Local droughts, detected by VHI-method.

The particularity of climate of Portugal is hot summer with low amount precipitation. According to "Iberian Climate Atlas" in July and August climate normal values of precipitation (1971-2000) are less then $30 \mathrm{~mm}$ almost for all territory of Portugal. By this reason second part of July-August is the period of fire activity, independently of amount of precipitation and drought occurrence. (Figure2) 

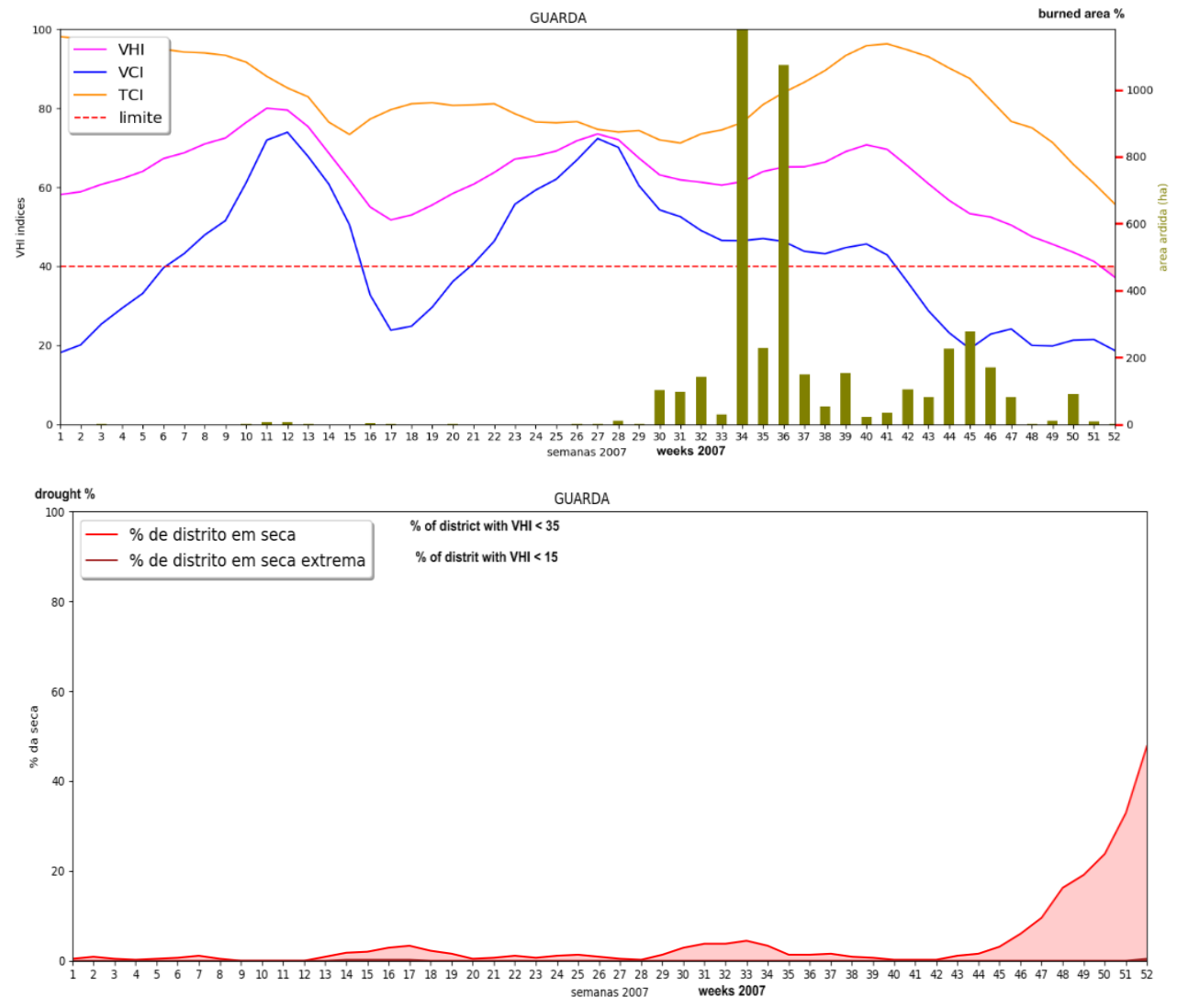

Figure 2 - Fire occurrence in summer 2007 and VHI analysis.

Visual analysis showed that local droughts, detected with VHI-method, are associated with fires activity frequently, especially in spring and autumn (Figure 3).
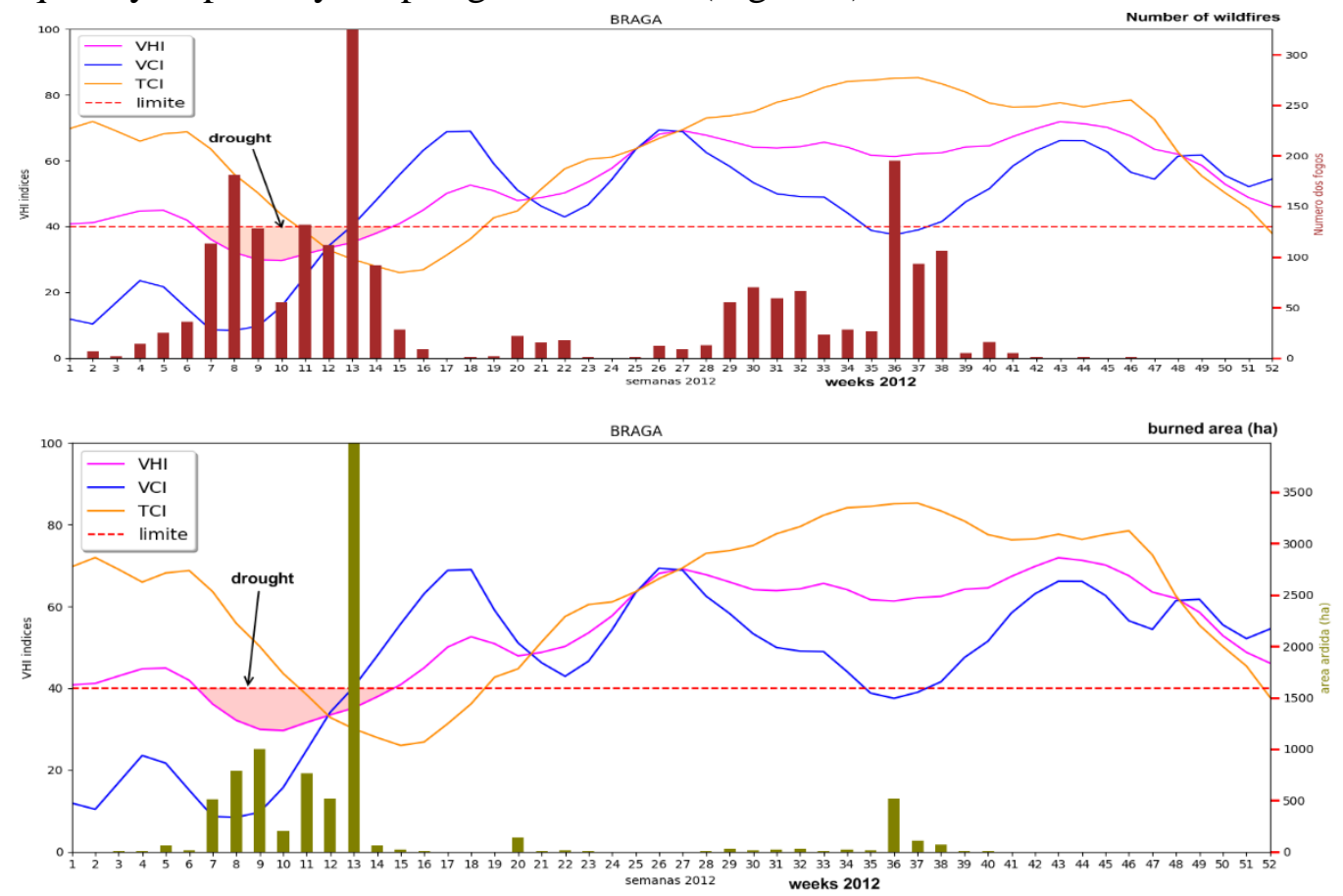


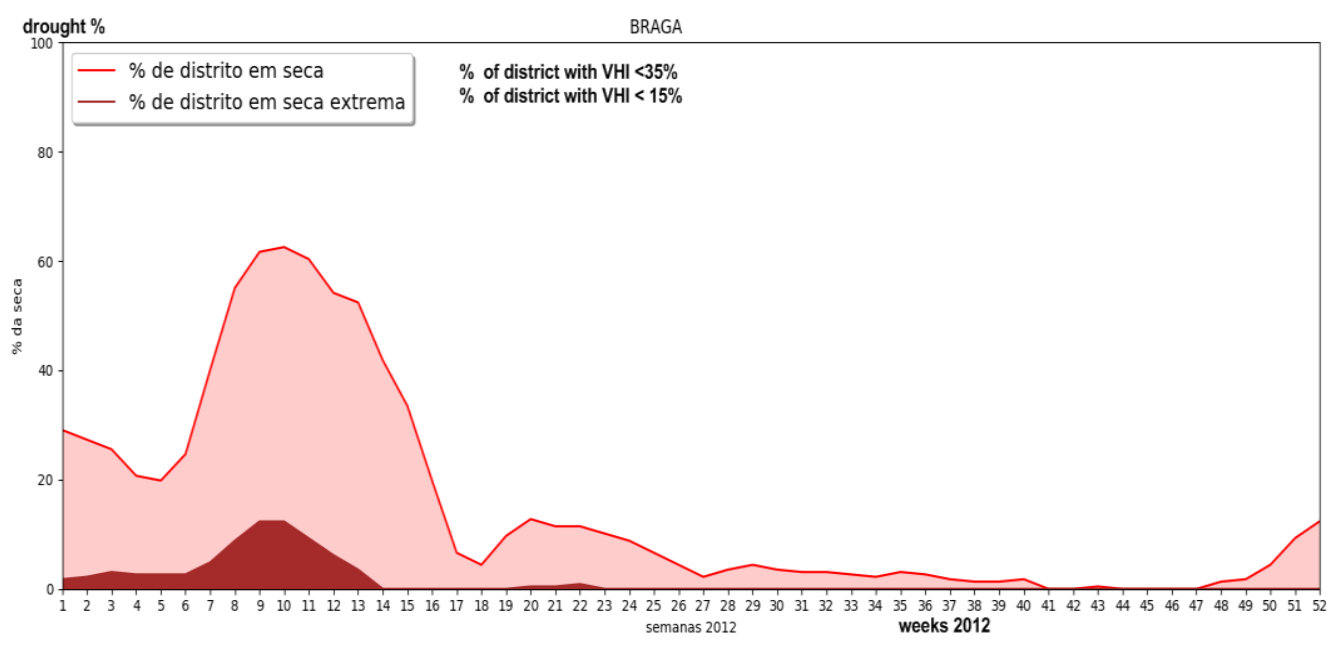

Figure 3 - Local drought, detected by VHI-method and fire occurrence in spring 2012

Fire conditions, controlled by climate and weather, which affect both fuel moisture (direct effect) and fuel structure (indirect effect). Fuel moisture determines availability to burn and fuel structure refers to the amount of burnable resources. It is well known, that fuel flammability and fire hazard increase in dry and warm years (Flannigan \& Harrington, 1988; Piñol et al., 1998; Founda \& Giannakopoulos, 2009). Fire activity may also increase when moist conditions precede the fire season, creating potential fuel (Keeley, 2004; Pausas, 2004; Littell et al., 2009; Archibald et al., 2010). In conditions of Mediterranean climate with dry, hot summer vegetation stress due to the lack of soil water or because of leaves excessive heating can lead to increasing fine fuel and flammable conditions.

By these reasons we compared correspondence of big fires (burned area $\geq 1000 \mathrm{ha}$ ) to the next conditions: 1) vegetation stress because of lack of soil water (VCI < 40.0); 2) leaves overheating (TCI $<40.0$ );3) percentage of area with droughts, detected by VHI-method, exceeded $20 \%$ of district.

Effectuated analyses showed, that for all districts, $88 \%$ of big fires have relation with at least one of the mentioned above conditions (Table1.)

Table 1 - A-number of wildfires with burned area > 1000ha;

B-number of wildfires, which correspond to drought or conditions of vegetation stress.

\begin{tabular}{|l|r|r|}
\hline DISTRICT & A & \multicolumn{1}{|c|}{ B } \\
\hline Aveiro & 12 & 11 \\
\hline Braga & 38 & 37 \\
\hline Bragança & 35 & 29 \\
\hline CBranco & 30 & 28 \\
\hline Coimbra & 22 & 14 \\
\hline Faro & 11 & 8 \\
\hline Guarda & 53 & 46 \\
\hline Leiria & 14 & 13 \\
\hline Porto & 27 & 25 \\
\hline Santarem & 23 & 20 \\
\hline Viana & 29 & 24 \\
\hline VilaReal & 48 & 45 \\
\hline Viseu & 52 & 47 \\
\hline & & \\
\hline total: & 394 & 347 \\
\hline
\end{tabular}

As was referred above, for each districts we calculated POD, FAR and Miss Ratio. Table 2 shows the results for the districts with frequent large forest fires.

We can see that false alarms (FAR) have very high percentages in all districts, which means that the district has a percentage of drought $20 \%$ or more, but there have been no forest fires with areas of 1000 ha or higher. Such situations occur often when assessing forest fire hazards. The ideal would be 
to decrease the value of false alarms. For this purpose it would have to increase the percentage of drought in the district, for example, to put $30 \%$ instead of $20 \%$, but also reduce the POD and increase the Miss Ratio.

The Miss Ratio aims to respond to how often it is expected that there is no event but it happens. The perfect value would be the null. As we can see, the value of miss ratio is very small, close to zero, for all districts.

The POD (probability of detection) indicates how many times the event occurred under the expected conditions (in this case drought percentage equal to or greater than 20). As we can see POD values are high for almost all districts, showing a good relation between the percentage of drought and big forest fires. With exception of Faro, Viana do Castelo and Coimbra, where this value is lower than 0.5, due to the high number of big fires in situations when the district's percentage of drought was less than $20 \%$.

Table2 - Probability of Detection (P.O.D), False Alarm Rate (F.A.R.) and Miss Ratio calculated from contingency table for Burned Area $>=1000$ ha and \%drought $>=20 \%$

\begin{tabular}{|l|rrr|}
\hline & P.O.D. & F.A.R. & MissRatio \\
\hline Aveiro & 0,69 & 0,93 & 0,01 \\
Braga & 0,74 & 0,85 & 0,01 \\
Bragança & 0,55 & 0,88 & 0,02 \\
Cbranco & 0,87 & 0,89 & 0,01 \\
Coimbra & 0,43 & 0,90 & 0,02 \\
Faro & 0,36 & 0,98 & 0,01 \\
Guarda & 0,79 & 0,85 & 0,02 \\
Leiria & 0,71 & 0,92 & 0,01 \\
Porto & 0,68 & 0,90 & 0,01 \\
Santarém & 0,78 & 0,93 & 0,01 \\
Viana & 0,38 & 0,88 & 0,02 \\
VilaReal & 0,80 & 0,82 & 0,02 \\
Viseu & 0,77 & 0,75 & 0,02 \\
\hline
\end{tabular}

In order to analyze the relationship between the number of weeks with burned area exceeding 1000 ha and the percentage of drought of each district:

- the percentiles for the district's weekly percentage of drought were calculated ;

- class were constructed: between the value of the $0^{\text {th }}$ percentile and $10^{\text {th }}$ percentile, between the value of the $10^{\text {th }}$ percentile and that of the $20^{\text {th }}$ percentile, etc .;

- for each class the number of weekly forest fires with burned areas equal or greater than $1000 \mathrm{ha}$ was calculated.

It was observed, that for all districts there is a relation between the highest values of the percentile of the district's drought percentage and the number of big forest fires. 

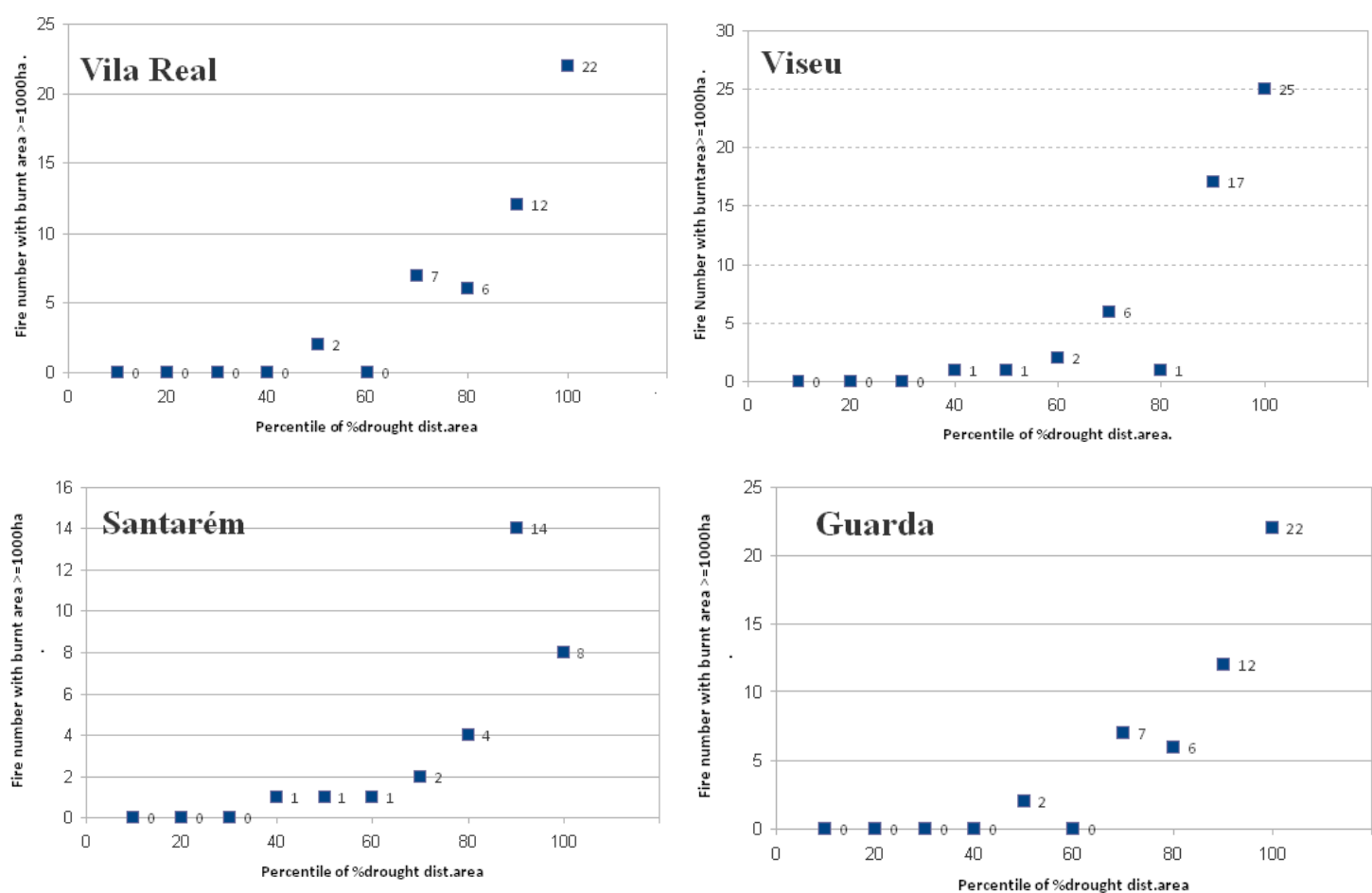

Figure 3 - Plot of the total number of weekly fires with burned area $\geq 1000 h a$, summed for each percentile class of the percentage of drought area of the district. Each point represents the total number of fires $(\geq 1000 h a)$ occurring in the class defined in this percentile

\section{Conclusions}

It is very difficult to establish the relationship between forest fires (area, number of events of big forest fires) and weather conditions, because the results depend on causes of another nature (such as population density and activity, socioeconomic conditions, cultural aspects, etc.)

The VHI index, as well as the sub-indexes VCI and TCI, show a strong relation both to the burned areas and to the number of events of forest fires. Graphs with the representation of these relations for some districts showed, as examples, on Figure 2 and Figure 3.

The analyses results showed, that for all districts, $88 \%$ of big fires have relation with at least one of next conditions, detected with VHI-method:

- vegetation stress because of lack of soil water (VCI <40.0);

- vegetation stress because the leaves overheating (TCI $<40.0$ );

- percentage of drought by district exceeded $20 \%$.

Also, the analysis with the contingency tables shows a close relationship between the percentage of drought area of a district and the burned area $\geq 1000$ ha, that is to say, that preferably the large forest fires occur if the district has a percentage of drought area $\geq 20$. This observation can also be made by analyzing the graphs of the number of fires with burned area $\geq 1000$ ha for each district in each class of percentage of drought area made based on the percentiles.

\section{References}

Archibald, S.,Nickless, A., Govender, N., Scholes, R.J. \& Lehsten,V. (2010) Climate and the interannual variability of fire in southern Africa: a meta-analysis using long-term field data and satellitederived burnt area data. Global Ecology and Biogeography, 19, 794-809. 
Cracknell AP. 1997. The Advanced Very High Resolution Radiometer (AVHRR). London: Taylor \& Francis. 534 p.

Flannigan, M.D. \& Harrington, J.B. (1988) A study of the relation of meteorological variables to monthly provincial area burned by wildfire in Canada (1953-80). Journal of Applied Meteorology, $27,441-452$.

Founda, D. \& Giannakopoulos, C. (2009) The exceptionally hot summer of 2007 in Athens, Greece a typical summer in the future climate? Global and Planetary Change, 67, 227-236.

Hayas, M.J. and Decker W.L. 1996. Using NOAA AVHRR data to estimate maize production in the United States Corn Belt. International Journal of Remote Sensing, 17, pp 3189-3200.

Iberian Climate Atlas (1971-2000), Instituto Portugues de Meteorologia, 2011, Lisboa, http://www.ipma.pt/resources.www/docs_pontuais/ocorrencias/2011/atlas_clima_iberico.pdf

Jurdao S, Chuvieco E, Arevalillo JM (2012) Modelling fire ignition probability from satellite estimates of live fuel moisture content. Fire Ecology 8(1). 77-97.

Keeley, J.E. (2004) Impact of antecedent climate on fire regimes in coastal California. International Journal of Wildland Fire, 13, 173-182.

Kogan F. 1997, Global Drought Watch from Space, Bulletin American Meteorological Society 78:621-636.

Kogan F. and Guo W. 2015. 2006-2015 mega-drought in the western USA and its monitoring from space data. Geomatic, Natural Hazards and Risk, DOI:10/1080/19475705.2015.1079265. http://dx.doi.org/10/1080/19475705.2015.1079265

Kogan F., GitelsonA., Zakarin E. and Lebed E., AVHRR-Based Spectral Vegetation Index for Quantitative Assessment of Vegetation State and Productivity: Calibration and Validation, 2003. $\begin{array}{lllll}\text { Photogrammetric } \quad \text { Engineering } \quad \& \quad \text { Remote } & \text { 69(8) }\end{array}$ https://digitalcommons.unl.edu/natrespapers/278

Kogan F., GitelsonA., Zakarin E. and Lebed E., Using AVHRR Data for Quantitative Estimation of Vegetation Conditions: Calibration and ValidationhttpsAdv. Space Res.,1998, Vol. 22, No.5. pp. 673--676.

Kogan F.N. 1995. Droughts of the Late 1980s in the United States as Derived from NOAA PolarOrbiting Satellite Data. Bulletin of the American Meteorological Society, 76 (5), pp. 655-667.

Kogan FN. 2001. Operational space technology for global vegetation assessment. Bulletin of the American Meteorological Society 82: 1949-1964.

Kogan, F. and Guo W. 2014, Early twenty-first-century droughts during the warmest climate. Geomatics, Natural Hazards and Risk http://dx.doi.org/10.1080/19475705.2013.878399

Littell, J.S., McKenzie, D., Peterson, D.L. \& Westerling, A.L. (2009) Climate and wildfire area burned in western US ecoprovinces, 1916-2003. Ecological Applications, 19, 1003-1021.

Mar Bisquert, Juan Manuel Sánchez and Vicente Caselles, 2014, Modeling Fire Danger in Galicia and Asturias (Spain) from MODIS ImagesRemote Sens. 2014, 6, 540-554.

P. Illera, A. Fernández \& J. A. Delgado (2007) Temporal evolution of the NDVI as an indicator of forest fire danger, International Journal of Remote Sensing, 17:6, 1093-1105.

Pausas, J.G. (2004) Changes in fire and climate in the eastern Iberian Peninsula (Mediterranean Basin). Climatic Change, 63, 337-350.

Piñol, J., Terradas, J. \& Lloret, F. (1998) Climate warming, wildfire hazard, and wildfire occurrence in coastal eastern Spain. Climatic Change, 38, 345-357. 